\title{
The occurrence and importance of Lophodermella sulcigena and Hendersonia acicola on Scots pine in Finland
}

\author{
RISTO JALKANEN
}

\begin{abstract}
JALKANEN, R. 1985: The occurrence and importance of Lophodermella sulcigena and Hendersonia acicola on Scots pine in Finland. - Karstenia 25: 53-61.

Specimens of Lophodermella sulcigena (Rostr.) v. Höhn. have been collected in Finland since 1893, and known epidemics have occurred in the years 1921-1924, 1946-1953, and from 1976 to today. The disease is now much more harmful than earlier. The northern line of the main distribution of Lophodermella needle cast has moved from the latitudes $61^{\circ}-62^{\circ}$ in the 1950 's to the Artic Circle in the $1980^{\prime}$ s. The most severe damage during the last epidemic was in 10-20-year-old even-aged Scots pine (Pinus sylvestris L.) plantations, occurring on the best forest sites but especially in abandoned fields. There were only a few scattered infected trees in plantations on poor pine heaths. The average height of the infected stands was $2-5 \mathrm{~m}$. The epidemic started first in southern Finland and spread to northern Finland in a few years. A reason for the susceptibility to L. sulcigena is the planting of pine in the best soils and fields. Hendersonia acicola Tub. occurred in Lophodermella needles a few years after the first infection, and seemed to finish the epidemic of Lophodermella needle cast. Two symptom types of Lophodermella needle cast are described according to the absence or presence of $H$. acicola in the needles infected primarily by L. sulcigena.
\end{abstract}

Risto Jalkanen, The Finnish Forest Research Institute, Rovaniemi Research Station, Eteläranta 55, SF-96300 Rovaniemi, Finland

\section{Introduction}

The common needle disease of Scots pine (Pinus sylvestris L.) in the late 1970's and early 1980's in Finland has been the Lophodermella needle cast caused by Lophodermella sulcigena (Rostr.) v. Höhn. The disease was clearly rarer in the 60's than in the 70 's. It occurs very clearly in some years, and then disappears for many years.

The Lophodermella needle cast seems to have become a problem to Scots pine growers just after cultivated plantations became common, although it was considered to threaten pines as early as the beginning of this century in Sweden (Lagerberg 1910) and later in Finland (Liro 1924a, Kujala 1950). Some features of the newest epidemic are reported. The report is a supplement to an earlier study (Jalkanen 1981).

\section{Material and methods}

The records of $L$. sulcigena in the collections of the botanical museums at the Universities of Helsinki (H), Turku (TUR) and Oulu (OULU), and of the Departments of Silviculture (HSI) and Plant Pathology (HPP) in Helsinki, and of the Finnish Forest Research Institute (HFR) were checked. For timing older epidemics literature was reviewed. A part of the newest samples (from the years 1976-1984) was sent to the Finnish Forest Research Institute by forestry professionals and forest owners.

The effects of forest site, stand development, age and height of the diseased stands on the amount of
Lophodermella needle cast were studied since 1976. The records were listed according to the biological provinces and the uniform grid system (Grid $27^{\circ} \mathrm{E}$ ) (see Heikinheimo and Raatikainen 1971).

A total of 330 Lophodermella records or mention thereof were found in 221 different localities; of these 27 were from before 1976, and 194 from the years 1976-1984. Stand age, height, method of regeneration and location in the forest/agricultural land were defined from 101 records and forest site from 138 records. These all were from the years 1976-1982. They were located mainly in southern Finland (south of the latitude $65^{\circ} \mathrm{N}$ ).

Also the occurrence of Hendersonia acicola Tub. in needles infected primarily by $L$. sulcigena was studied. In the first stage the occurrence of conidia and pycnidia on, and the brittleness and basal colour of the diseased needles were checked. To make $H$. acicola easily visible a moist chamber was used. A shoot with symptoms of Lophodermella needle cast was placed in a plastic bag with $10-20 \mathrm{ml}$ tap water. Closed bags were kept in room temperature and checked in ten days. $1 \%$ malt-extract-agar was used as the culture medium.

Records of L. sulcigena and H. acicola in Finland are listed in another paper (Jalkanen 1985).

Two sub-trials of two progeny tests of Scots pine proved to be infected by L. sulcigena in 1978. The tests have been established by the Department of Genetics, the Forest Research Institute. The occurrence of Lophodermella needle cast was surveyed in other sub-trials. The amount of the needle cast was classified for every tree according to Jalkanen (1982). Also some material was collected in seed orchards.

Susceptibility of the lodgepole pine (Pinus contorta Loud.) 

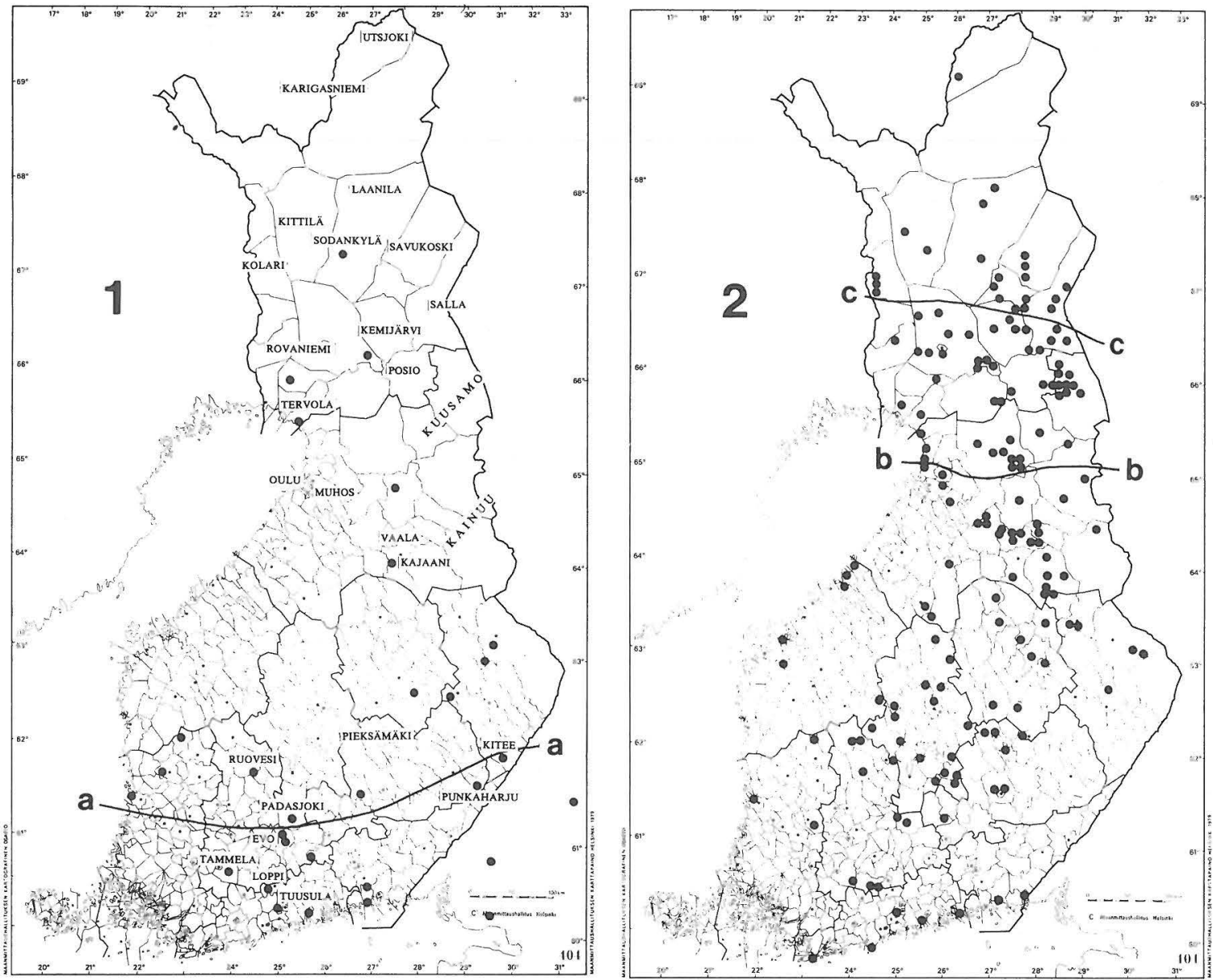

Figs. 1-3. Lophodermella sulcigena and Hendersonia acicola. - 1: Occurrence of Lophodermella needle cast in Finland before 1976. a = northern line of significant occurrence of $L$. sulcigena in 1950 (according to Kujala 1950). - 2: Occurrence of Lophodermella needle cast in 1976-84. Northern line of significant occurrence of L. sulcigena at the end of 1979 (b) and 1984 (c). - 3: Occurrence of Hendersonia acicola in Finland in 1924-1984.

to L. sulcigena was illustrated in a provenance trial, which was established by the Foundation of Forest Tree Breeding at Loppi, southern Finland, in 1972. A total of 114 lodgepole and 2 Scots pine provenances were planted in a randomized block design with 12 one-tree plots (Hahl 1978). The incidence of Lophodermella needle cast was surveyed in the years 1978 - 1979 according to the classification by Jalkanen (1982).

\section{Results}

The occurrence of Lophodermella needle cast before 1976

Lophodermella needle cast has been found in nearly all parts of Finland (Fig. 1). The oldest records date back to the infections of the years 1893 and 1894 in Evo, Central Finland. The collector was probably J.E. Furuhjelm, who lived at Evo for a long time and collected a lot of botanical samples for the herbarium HSI (pers. comm. by Dr. A. Koponen). The shoot collected 15th June 1894 had abundant apothecia. The shoot collected on 16th August 1894 had reddish brown needles with purplish black dots. The collector had identified them as Hypoderma sulcigenum and ' $H$. sulcigenella' but with a question mark.

In South Finland V.A. Seppälä collected the fungus at Tammela on 8th August $1914(\mathrm{H})$, and $\mathrm{O}$. Heikinheimo from Ruotsinkylä, Tuusula on 5th February 1924 (HFR). There was obviously an epidemic of Lophodermella needle cast in the 1920's, because Liro (1924a) wrote an article about the disease, asking for samples from the countryside. $L$. sulcigena occurred at Siikakangas, Ruovesi (Central Finland) in the years 1921-1923 (Hertz 1926) and also in 1929 (Kangas 1931).

The Lophodermella needle cast was found in different parts of southern Finland in 1932-1935 (Kangas 1937). His mention of Sodankylä can't be considered reliable.

A severe epidemic occurred in the years 19461953. Samples exist from the year 1948 , containing a note that the disease destroyed needles already in 


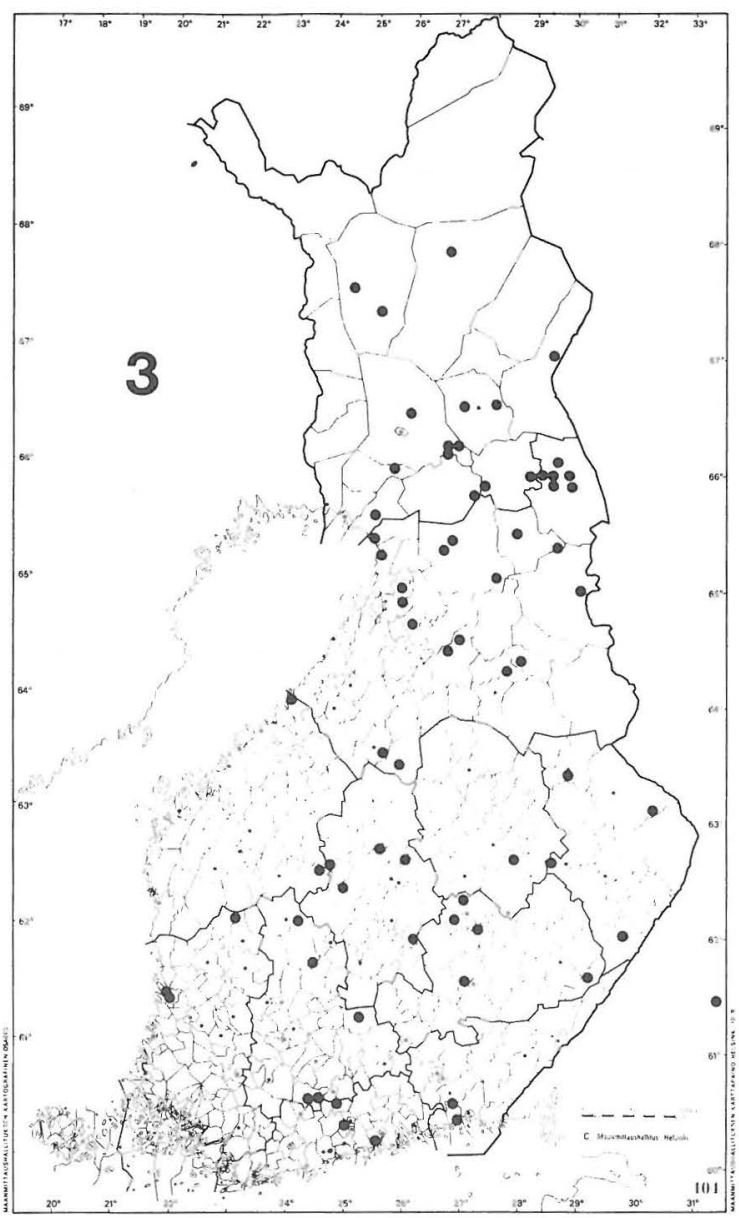

1946 (e.g., at Punkaharju; HFR). Most of them were collected by V. Kujala (HFR); his samples are mainly from southern and southeastern Finland, the northern most ones being from Lintupirtti, Tervola. According to Kujala (1950), the Lophodermella needle cast was significant and common southwards from the line Padasjoki-Punkaharju-Kitee. Vaartaja (1951) reported the disease in $1948-1950$.

After the last-mentioned epidemic only four records are known, based on collections in 1966 by T.Kurkela and V. Hintikka (HFR).

Hendersonia acicola is present in both shoots from the year 1924. It is very common in samples of the years 1948-1953, and was mentioned for the first time from Finland during that epidemic (Kujala 1950).

The occurrence of Lophodermella needle cast in 1976-1984

Distribution

The first records were from 1976. Heavy infections occurred in large areas of southern and central Finland in the years 1977-1978, and the disease spread to the stand level (the majority of the trees in the stand infected). Some healthy stands were infested further in 1979, when original stands started to recover. The epidemic became less significant in southern and central Finland in 1981, when all the severely infected stands had recovered. Single needles with ripe apothecia were still seen in these stands in early June 1982.

Already in the years 1977-1978, the Lophodermella needle cast affected pine within the main range of $L$. sulcigena, i.e., from the south coast to the latitude $65^{\circ} \mathrm{N}$ (line b in Fig. 2). The disease was common everywhere in central Finland. In Kainuu the most severe infestation years were 1979-1981 (Anonymous 1980, 1981, 1982). The first records of the spread of the disease to northern Finland were made at the end of 1970 's, but judging by the cast of needles, $L$. sulcigena has started to infect them in northern Finland mainly in the 1980's. In the summer 1981 Lophodermella needle cast spread distinctly northwards. The next year's infection was less severe, and some trees even appeared healthy even though they had been infested for some years before. Also in the Kuusamo highland area, Lophodermella needle cast broke out in the rainy summer of 1981, although some trees had lost needles already in 1979. The epidemic expanded in 1982, but still trees were only slightly infected.

Summer 1983 was again a year of strong spread: new diseased trees and stands appeared abundantly north of the Arctic Circle. No new areas in the North were found in summer 1984, but in older areas (especially those infected a year before) Lophodermella needle cast was severe. In northern Finland the disease has been especially common in Kuusamo, Kemijärvi and in the area east of Oulu.

After some disease-free years, $L$. sulcigena started to infect single trees and even stands in southern and central Finland again in 1983. It was especilly common in those stands, which had been diseased already at the end of 1970 's. Reinfections occurred for instance in progeny tests. In central Finland there were trees diseased for the first time in 1983. After the summer 1984, the Lophodermella needle cast seemed again to be present everywhere in central Finland. Single records were received even from the south coast.

At the end of the year 1984 the northernmost observations were from Kolari $\left(67^{\circ} 20^{\prime} \mathrm{N}, 2^{\circ} 45^{\prime} \mathrm{E}\right)$, Kittilä, Sodankylä $\left(68^{\circ} 15^{\prime} \mathrm{N}, 27^{\circ} 40^{\prime} \mathrm{E}\right)$, Savukoski and Salla $\left(67^{\circ} 10^{\prime} \mathrm{N}, 29^{\circ} 10^{\prime} \mathrm{E}\right)$. The northernmost record from Finland was found by Dr. T. Kurkela in Karigasniemi, Utsjoki $\left(69^{\circ} 25^{\prime} \mathrm{N}, 25^{\circ} 50^{\prime} \mathrm{E}\right)$. The tree was heavily infected in 1984. Severely diseased saplings occurred at $340 \mathrm{~m} \mathrm{s.m}$. in lush plantations of fertile soil in Kuusamo. Mature ascomata were found in June-July in the northernmost localities.

All the lodgepole pine provenances in the provenance trial in Halkivaha, Loppi were healthy in the survey years of 1978-1979. Instead, both Scots pine provenances were diseased in both summers, losing ca. $7 \%$ of needles in 1978 .

Regeneration $v$.s. forest site of the stand

L. sulcigena either infected only a few scattered trees, 
or spread widely, affecting majority of trees in the stand. In the following the former case is called 'scattered trees' and the latter one 'stand' or 'standlevel'.

The majority of the records from the years 19761982 were from southern and central Finland. In northern Finland $L$. sulcigena occurred mainly in scattered trees, being at stand-level only at Muhos, Vaala, in some abandoned fields near Oulu, at Posio and Rovaniemi. Later (1983-1984) the stand-level was seen more generally, especially in Kuusamo, Kemijärvi and Oulu.

Scattered, infected trees grew in stands of even or variable age, for instance on roadsides and peatlands. Nearly $95 \%$ of stands were born naturally and only $5.7 \%$ by cultivation. Most $(83.3 \%)$ stand-level records were from plantations (Table 1): naturally born stands seldom had abundant Lophodermella needle cast. Correspondingly, in plantations the disease was common in most cases (93\%).

One third (34) of all the records in 1976-1982 were from abandoned fields. From stand-level records

Table 1. Occurrence of Lophodermella needle cast in natural and cultivated stands of pine according to the material collected in $1976-1982(n=101)$.

\begin{tabular}{lrrrrr} 
& \multicolumn{4}{c}{ Trees with L. sulcigena in the stand } \\
Method of & \multicolumn{2}{c}{$\begin{array}{c}\text { Abundantly } \\
\text { regeneration }\end{array}$} & No & \multicolumn{2}{c}{ Scattered } \\
ren & No & \multicolumn{1}{c}{$\%$} \\
\hline Natural regeneration & 8 & 16.7 & 50 & 94.3 \\
Cultivation & 40 & 83.3 & 3 & 5.7 \\
\hline Total & 48 & 100.0 & 53 & 100.0
\end{tabular}

Table 2. Occurrence of Lophodermella needle cast on forest land and in stands in abandoned fields according to the material collected in 1976-1982 (n $=101)$.

\begin{tabular}{lrrrr}
\multirow{2}{*}{ Site } & Trees with L. Sulcigena in the stand \\
& \multicolumn{2}{c}{ Abundantly } & \multicolumn{3}{c}{ Scattered } \\
& No & $\%$ & No & $\%$ \\
\hline Abandoned field & 27 & 56.2 & 7 & 13.2 \\
Forest land & 21 & 43.8 & 46 & 86.8 \\
\hline Total & 48 & 100.0 & 53 & 100.0
\end{tabular}

more than a half $(56.2 \%)$ were in the fields. In the forest land two-thirds of the cases were on the scattered tree level, as compared to one-fifth in fields (Table 2). This means that in most cases nearly all trees in a field plantation were diseased (in most cases there was a great number of trees, which had lost all their current year's needles). The part of a progeny test, which was in a field, had only a few healthy trees $(7.3 \%)$ compared to the part on forest land $(54.9 \%)$.

The occurrence of the Lophodermella needle cast in the stand level was maximal in the best forest sites: the proportion of fields and forest sites of the categories 'very rich', 'rich' and 'medium' (fresh) was $90.4 \%$, and only $9.6 \%$ of observations was on poorer forest sites (Table 3). Scattered tree observations seemed to be concentrated on significantly poorer soils than the ones at the stand level. A significant part of them were on sub-dry forest sites, which are considered more suitable for Scots pine than for Norway spruce (Picea abies (L.) H. Karst.). In the whole material (138 records) the proportion of medium or better forest sites was two thirds, or excluding fields, $55.8 \%$. The proportion of fresh and sub-dry forest sites (this means the southern Finnish forest site types Myrtillus type, MT, and Vaccinium type, VT) was $87.5 \%$ and that of only medium sites $51.0 \%$. No observations were made on the very dry sites and the proportion of dry sites was negligible $(5.8 \%)$.

L. sulcigena infected trees on the peatlands, especially in field plantations, too.

\section{Height and age of diseased trees}

The average height of stand-level observations varied between one and 9 meters. At best the height of dominant trees exceeded $10 \mathrm{~m}$. Most trees with standlevel observations were $2-5 \mathrm{~m}$ tall (Fig. 5). Single scattered trees were significantly higher (between 3 and $14 \mathrm{~m}$ ) than trees at the stand-level. Disease was seen also in trees of older stands: the thickest were at breast height over $0.2 \mathrm{~m}$ in diam. In the stand-level, Lophodermella needle cast was not seen in stands other than sapling stages, but after 1983 there were plenty of stand-level observations of older stages from northern Finland.

Lophodermella needle cast was recorded on trees of under 10 to 60 years old. It seems that in northern Finland it can infect older trees than in southern Finland, although due to shorter trees in northern

Table 3. Occurrence of Lophodermella needle cast in different forest sites according to the material collected in $1976-1982(\mathrm{n}=138)$.

Trees with L. sulcigena in the stand

\begin{tabular}{lrrrrrr} 
Forest site type & \multicolumn{2}{c}{ Abundantly } & \multicolumn{2}{c}{ Scattered } & \multicolumn{2}{c}{ Total } \\
& No & \multicolumn{1}{c}{$\%$} & \multicolumn{1}{c}{ No } & \multicolumn{1}{c}{$\%$} & \multicolumn{1}{c}{ No } & \multicolumn{1}{c}{$\%$} \\
\hline Abandoned field & 27 & 51.9 & 7 & 8.1 & 34 & 24.7 \\
Rich or very rich sites & 3 & 5.8 & 2 & 2.3 & 5 & 3.6 \\
Fresh sites & 17 & 32.7 & 36 & 41.9 & 53 & 38.4 \\
\hline Sub-dry sites & 4 & 7.7 & 34 & 39.5 & 38 & 27.5 \\
Dry sites & 1 & 1.9 & 7 & 8.1 & 8 & 5.8 \\
Barren sites & - & - & - & - & - & - \\
\hline Total & 52 & 100.0 & 86 & 100.0 & 138 & 100.0
\end{tabular}




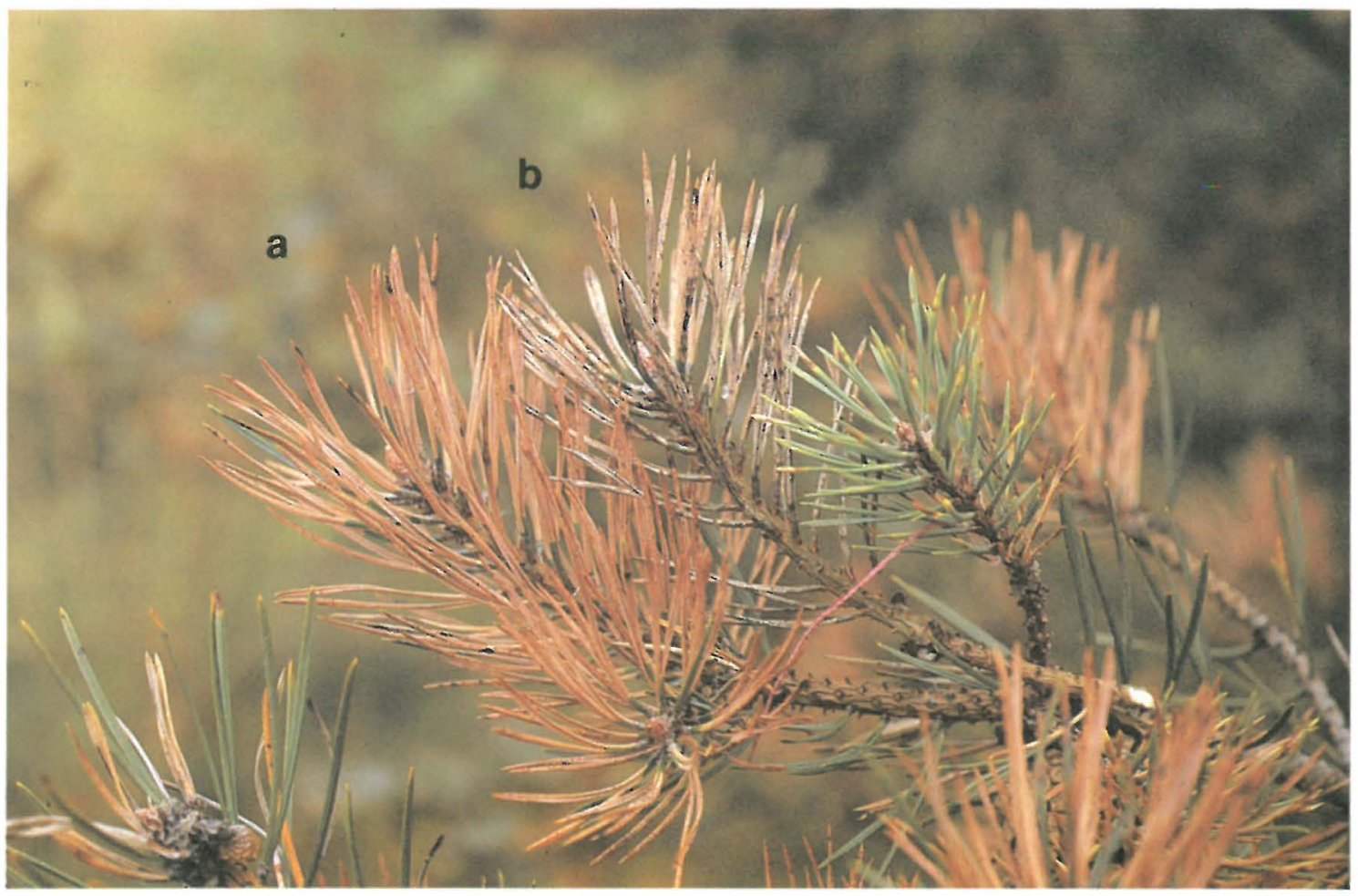

Fig. 4. The colour of needles infected by Lophodermella sulcigena without (a) and with Hendersonia acicola (b). Rovaniemi, Finland, 2 September 1983.

Finland the disease is easier to observe there. Two over 200-year-old diseased pines were found in the autumn 1984 in Salla and Kuusamo. The diseased scattered trees were generally older than trees at stand-level, of which $83 \%$ were in the age class under 20 years (Fig. 6).

\section{Occurrence in progeny collection}

tests and seed orchards

The first stand-level records in the 1970's were confirmed in two progeny collections in Loppi. The disease had affected there some trees already in 1976. During the following four years 75 to $83 \%$ of trees in one collection were infected. In 1981 only $3 \%$ of the trees were slightly infected; the stand was healthy in 1982. However, some trees were reinfected in 1983. The average time for a tree to be diseased was 3 to 4 years.

A sub-trial of a progeny test was reported to be infested by $L$. sulcigena in autumn 1978 near Pieksämäki. This belongs to a group of eleven subtrials. Five of them situated in the main distribution area of Lophodermella needle cast, and proved to be infested by the disease (for the sub-trials, see Jalkanen 1982). Other sub-trials near the Gulf of Finland and in northern Finland stayed healthy.

Lophodermella needle cast was recorded in some seed orchards of Scots pine, too. Results are reported in another connection. There are great genetical differences in susceptibility to $L$. sulcigena between clones and progenies (Jalkanen 1982).

\section{Hendersonia acicola in needles \\ infected by L. sulcigena}

Needles infected by $H$. acicola turned gray already in August - September. The grayness started from the base, spreading during the winter to the whole needle. At the same time the needles started to weaken quickly, and they broke down easily already in the autumn, when also black conidia of $H$. acicola flushed onto the gray needle surfaces. No apothecia of $L$. sulcigena were seen.

In spring the needles with apothecia were light brown with dark spots, and flexible. They stayed quite firmly in the shoots.

The existence of $H$. acicola was often difficult to prove without inoculation. Observing conidia was easiest in September - October (especially in rainy autumns) and in May - June.

$H$. acicola was present in nearly as wide an area as L. sulcigena (Fig. 3). The first observations from the latest epidemic were made in May 1978 in the progeny collection in Loppi, where also Lophodermella needle cast at stand level was first seen. Conidia were common on pine needles infected by $L$. sulcigena during 1978-1980 in southern and central Finland. 

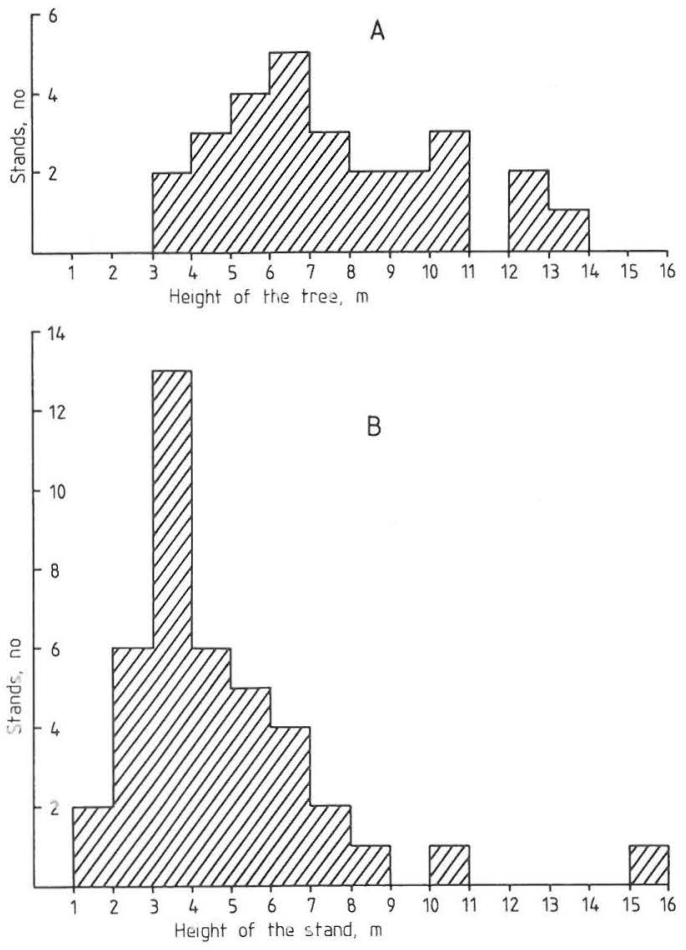

Fig. 5. Height of single scattered trees (A) and stands (B) affected by Lophodermella sulcigena according to the material collected in 1976-1982 $(n=101)$.
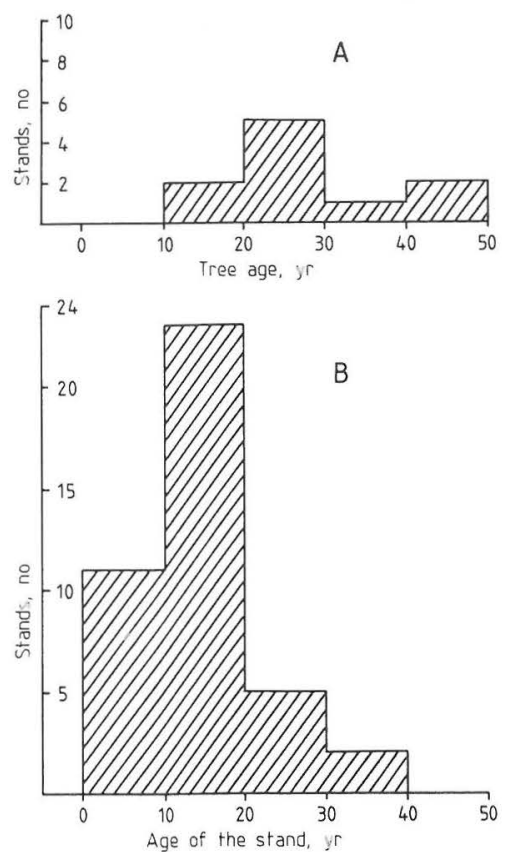

Fig. 6. Age of single scattered trees (A) and stands (B) affected by Lophodermella sulcigena according to the material collected in $1976-1982(n=101)$.
Already along the line Oulu - Kajaani H. acicola occurred more irregularly and later than in southern Finland. It was isolated from north Finnish samples only in the 1980's, mainly in 1981-1984. The trees with Lophodermella did not yield $H$. acicola in 1982 , but did so in some cases the next year.

The symptoms of $H$. acicola were best seen in the lowest branches. There were great differences in the occurrence of $H$. acicola between neighbour trees, which all were infested by $L$. sulcigena. In Rovaniemi and Kuusamo isolations of $H$. acicola were first positive in autumn 1982. Still, no conidia on the needles were found. The longer Lophodermella needle cast had affected, the shurer it was that $H$. acicola was present in the same tree. Yet in autumn 1984 many trees were free of $H$. acicola, especially in the northern line of the occurrence and in trees which had been infested first in 1984.

When $H$. acicola was abundant in the autumn, the tree seemed to be healthy or only slightly diseased after the following season. In other trees apothecia of L. sulcigena formed normally in all the years 1982 1984 in the northern observation area.

The secondary infestion of $H$. acicola could be confirmed $1-3$ years after the beginning of the Lophodermella epidemic. When a new epidemic occurred in 1983 in the same southern Finnish stands, $H$. acicola was present in general. However, trees or stands had seldom or never $H$. acicola during the first year of the Lophodermella epidemic.

$H$. acicola was seen only in trees and needles which were primarily infected by $L$. sulcigena.

The oldest observations of $H$. acicola were made from both samples of the year 1924 (HFR). Liro (1924b) mentioned the fungus, possibly according to Lagerberg (1910). The first definite Finnish record was published by Kujala (1950).

\section{Discussion}

Changes in the incidence and significance of Lophodermella needle cast in Finland

Almost 100 years have passed since the first find of $L$. sulcigena on Scots pine in Finland. The pathogen was described and named only 10 years earlier in Denmark (Rostrup 1883). Lophodermella needle cast was poorly known at that time, although its symptoms were known already in the early 1800's (Liro 1924b). Elfving (1905) possibly described the Lophodermella needle cast, when he mentioned an unknown needle disease together with snow blight (Phacidium infestans Karst.) from the years 1895 and 1903-1904. Rainio (1906) has no observations of it in Finland.

It seems that Lophodermella epidemics have occurred every $10-15$ years in Finland: in 18931894, (1903-1904), 1914, 1921-1923, 1933-1935, $1946-1953,1966$ and from the year 1976 onwards. The most noticeable of them were in the beginning of 1920's (Liro 1924a, Hertz 1926), in 1946-1953 (Kujala 1950, Vaartaja 1951), and the present one, which started in 1976. The last-mentioned epidemic is the most significant so far.

Between the peaks, L. sulcigena is to be found at least in single trees and needles (e.g. in the year 1929, 
Kangas 1931). It probably occurs all the time somewhere in Finland or in neighbouring countries as a weak population, which becomes an epidemic after favourable conditions, similarly to Lophodermium seditiosum Staley (Kurkela 1979).

In Sweden the Lophodermella needle cast was considered a threat to Scots pine seedling stands in the early 1900's (Lagerberg 1910), south of the latitude $60^{\circ} 30^{\prime} \mathrm{N}$. According to Kujala (1950) the significant line in Finland at the end of 1940's was approximately $100 \mathrm{~km}$ farther north than Lagerberg's (1910) line, and the pathogen was considered rare and southern in distribution. Thus the importance of $L$. sulcigena has increased significantly up to the 1970's and 1980 's, when the main distribution area reached first the latitude of $65^{\circ} \mathrm{N}$ and then the Arctic Circle. The disease may become a greater threat to northern Finnish sapling stands, because it has been able to produce mature ascocarps also in the northernmost infested pines in Karigasniemi and Laanila. Earlier Lagerberg (1910) mentioned Lophodermella needle cast from Ylitornio $\left(66^{\circ} \mathrm{N}\right)$ and Jørstad (1928) from the northern coast in Alta $\left(70^{\circ} \mathrm{N}\right)$. Before the 1970's the northernmost Finnish sample of $L$. sulcigena was from Tervola (HFR). There is some doubt on the record by Kangas (1937) from Sodankylä.

\section{Reasons to the epidemics}

The plantation forestry has quickly increased evenaged stands of Scots pine closing in young stage. At the same time a large amount of abandoned fields have been afforested, mainly with Scots pine (e.g., Selby 1980). The planting of Scots pine in the best forest sites has also increased (e.g., Varmola 1980).

The most severe Lophodermella needle cast damage was seen in 10-20-year-old plantations in fields, which belong to the best soils found in the country. Normally the disease had spread into the whole stand. Lush tree growth can be connected to the susceptibility of Lophodermella needle cast, as observed also by Krutov (1979) in Karelian A.S.S.R., and Vaartaja (1951) in Finland.

Abundant Scots pine plantations occur on soils, which are richer than pine's natural habitats and originally occupied by Norway spruce. The observed severe damage in fresh or still better forest site types is comparable to the results of Varmola (1980), where the proportion of stands with needle casts in general was $44.4 \%$ in rich forest site types (OMT), $13.2 \%$ in fresh forest site types (MT) and $2.0 \%$ in sub-dry forest site types (VT). The results support the opinion, that

1) in the plantation forestry Scots pine has often been planted on sites which are 'too good', which results in the loss of the natural resistance of Lophodermella needle cast;

2) as regards the susceptibility of Scots pine to $L$. sulcigena, the natural, so-called pine and spruce habitats are possibly to be considered separately. The line between these groups seems to lie between subdry and fresh (medium) forest site types.

Because severely diseased stands were mostly established with seedlings, the connection of susceptibility with planting seemed to be evident.
Still, this is misleading: severe damage was concentrated on best soils, were mainly cultivated stands of Scots pine can exist. The fertility of the soil affects the susceptibility by changing the structure of needles, for instance the size of stomatal occlusions (Jalkanen et al. 1981). The nutrient imbalance in needles (which includes high $\mathrm{N}$-content) increases in good soils and leads to the weakening or disappearance of resistance to Lophodermella needle cast (Kurkela and Jalkanen 1981).

If the susceptibility to L. sulcigena depends on growth rate, the restricted occurrence of Lophodermella needle cast in northern Finland can partly be explained by the low growth rate. This should be examined in later programs. Similar positive correlation between growth rate and susceptibility exists between Scots pine and pine twisting rust (Melampsora pinitorqua Braun.: Jalkanen and Kurkela 1984). This kind of resistance is likely structural, but also biochemical (Jalkanen et al. 1981), which is basically defined by genetical factors. Because L. sulcigena has a normal life cycle in the North, the short growing season itself cannot be directly restricting the spread to healthy trees.

Healthy shedding needles of pine are $3-4$ years old in southern Finland, compared to 7-8 years in Lapland. So a three-year epidemic of $L$. sulcigena is much more harmful in the South than in the North. Lagerberg (1910) and Jørstad (1925) believed that a tree can possibly be killed by Lophodermella needle cast, but I recorded no deaths even after subsequent infestations of $L$. sulcigena, while there were nearly needleless pines in diseased stands. However, Ms. Signe Berlin (in litt., specimen in HFR) reported that 'In some cases the loss of needles has been so severe that the tree has died in the following year'.

Although only a small part of provenance trials in Finland (Hagman 1974) were surveyed for this report, strikingly many progeny tests were heavily infested. For instance, in a progeny test in the main epidemic area, over $70 \%$ of sub-trials ( $52 \%$ of trees) were diseased. According to Varmola (1980) only $3 \%$ of trees in plantations of an average age of 20 years had needle casts in 1979, and (Varmola, pers. comm.) needle cast was detected in $10.4 \%$ of southern Finnish plantations. Varmola's (1980) term 'needle casts' seems to represent Lophodermella needle cast because it has been the only reported common needle disease in older plantations in Finland (Jalkanen 1981). Here and there in SE Finland Lophodermella conjuncta Darker (Kurkela 1978) has killed older needles.

Because of the significant retarding effect of $L$. sulcigena on the growth (Mitchell et al. 1976b) the influence of artifial speeding of the growth rate on the susceptibility of pine (cf. Jalkanen and Kurkela 1984) should be examined. There are significant differences in susceptibility between progenies and between clones (Lagerberg 1910, Jalkanen 1982). This should be used in resistance breeding, which is believed to help in producing more hardy trees (Terrier 1944, Roll-Hansen 1969).

The resistance of $P$. contorta to $L$. sulcigena was shown as reported by Karlman (1984), too, although 
this has not always been quite certain (Kujala 1950, Karlman 1980, Martinsson 1982).

One or two-year-old seedlings in nurseries seem to maintain their resistance in Finland (Liro 1924a). Older ones resemble the seedlings in nature, thus they can possibly be infested. The fungus possibly sporulates too late as compared to the growth of needles of nursery seedlings. Because L. sulcigena can infect needles during their growth in early summer and symptoms appear in July - August, there is no danger of bringing infected but healthy-looking seedlings into the forest.

\section{Role of Hendersonia acicola in an epidemic}

$H$. acicola seemed to become abundant about two years after the beginning of the Lophodermella epidemic and to lead later to recovery of these trees and stands. $H$. acicola was seen only on trees with the primary infection by $L$. sulcigena: this was also reported by Millar (1970), and Watson and Millar (1971). Also other Hendersonia species have reported to be connected with Lophodermella species (Darker 1967, Czabator et al. 1971, Staley and Bynum 1972).

Because $H$. acicola has antagonistic effects (Mitchell et al. 1976a), the absence of $H$. acicola from the northernmost trees allow L. sulcigena to continue infestions from the year 1985 onwards, perhaps leading to the death of these trees. In every case the fungus in these trees can produce ascospores every year, remaining as infection sources.

In addition to possible hyperparasitical effects, $H$. acicola can hinder the life cycle of $L$. sulcigena by speeding up the decomposition and desiccation of needles colonized by $L$. sulcigena. The needles start to break down in the autumn of infection and shed down before the next season (Williamson et al. 1976), especially at the end of the epidemic, when the disease has affected the tree $2-3$ years. In the beginning of the epidemic the needles stay in shoots until the second autumn, and L. sulcigena can sporulate in them, which has been stated by Terrier (1944), too. These shedding needles are flexible, with good structure and light brown colour (they do not break down from the needle base).

According to this report there seems to be two symptom types of Lophodermella needle cast. They are separated according to the colour and structure of autumnal needles, and by the occurrence of $H$. acicola in the needles. The types are: A) typical reddish brown flexible needles, without $H$. acicola infection, and B) brittle, easily breaking gray needles with $H$. acicola infection.

In type $A$ the needles infested primarily by $L$. sulcigena turn reddish brown in the autumn, stay firmly in the shoots (except in the case of hypersensitive reaction, which seems to lead abnormal early shedding), and do not break down. In type $B$ the needles turn gray already in the infection autumn, and needles start quickly to decompose and break down. They also lose and shed easily; the formation of the ascocarps of L. sulcigena is hindered. The differences between types $\mathrm{A}$ and $\mathrm{B}$ are best seen in the autumn and some years after the beginning of a Lophodermella epidemic (Fig. 4). The types develop best in areas of hard winter: mild or short winter might make it possible that other fungi confound the development of the types described here.

When considering $H$. acicola as a silviculturally dangerous pathogen, Kujala (1950) evidently examined samples from the late stage of the epidemic, when $H$. acicola has been abundantly present and possibly influenced significantly the disease symptoms. Samples in HFR collected by Kujala at the end of 1940's were rich in $H$. acicola spores. H. acicola is not to be considered a pathogen. The species was described from needles infected by $L$. sulcigena (Münch and Tubeuf 1910).

According to Mitchell et al. (1976a) in Scotland the antagonistic effect of $H$. acicola to $L$. sulcigena appear only when $H$. acicola infects needles in the autumn (so-called early secondary infection). When the fungus invades the needles in spring (late secondary infection), apothecia of L. sulcigena can develop in these needles. This seemed to happen in Finland, too.

In conclusion, there seems to be a possibility to control L. sulcigena biologically using $H$. acicola as a controller. In further studies this aspect should be taken as a serious issue.

Acknowledgements. The author wants to thank Dr. Lalli Laine for the help in finding and arranging Lophodermella needle cast samples, and Mr. Tarmo Aalto for technical assistance in preparing the manuscript.

\section{References}

Anonymous 1980: Kainuun piirimetsälautakunnan toimintakertomus 1979 . - 23 pp. Kajaani.

- 1981: Kainuun piirimetsälautakunnan toimintakertomus 1980. - 26 pp. Kajaani.

- 1982: Kainuun piirimetsälautakunnan toimintakertomus 1981. - 25 pp. Kajaani.

Czabator, F., Staley, J. \& Snow, G. 1971: Extensive southern pine needle blight during 1970-1971, and associated fungi. - Plant Dis. Rep. 55: 764-766.

Darker, G. 1967: A revision of the genera of the Hypodermataceae. - Can. J. Bot. 45: 1399-1444.

Elfving, K. 1905: Sjukdomar och sjukdomsorsaker i skogskulturer. - Suomen Metsänhoitoyhd. julk. 22: 82-134.

Hagman, M. 1974: Metsäntutkimuslaitoksen metsänjalostuksen tutkimusosaston suunnittelemat kenttäkokeet. - 189 pp. Metsäntutkimuslaitos, Helsinki.

Hahl, J. 1978: Tuloksia kontortamännyn alkuperäkokeesta Lopella. Summary: Results from an eight-year old provenance trial of lodgepole pine (Pinus contorta Dougl.). - Metsänjalostussäätiö, tied. 4: $1-8$.

Heikinheimo, O. \& Raatikainen, M. 1971: Paikan ilmoittaminen Suomesta tallennetuissa biologisissa aineistoissa. Summary: The recording of localities of biological finds in Finland. - Ann. Ent. Fenn. 37(1a): $1-27$.

Hertz, M. 1926: Silmäys Siikakankaan metsänviljelyksiin. - Metsätal. Aikak. 6: 197-204.

Jalkanen, R. 1981: Harmaakariste männyllä. Kirjallisuuskatsaus. Abstract: Lophodermella sulcigena on pines. A literature review. - Folia For. 476: 1-15.

- 1982: Lophodermella sulcigena in clones and progenies of scots pine in Finland. - In: Heybroek, H., Stephan, B. \& von Weissenberg, K. (eds.). Resistance to diseases and pests in forest trees: $441-447$. Pudoc, Wageningen.

- 1985: luettelo suomalaisista harmaakaristehavainnoista ennen vuotta 1985 mukaan lukien Hendersonia acicola. 
Summary: List of records of Lophodermella needle cast incl. Hendersonia acicola in Finland before the year 1985. - Metsäntutkimuslait. tiedonantoja (manuscript).

Jalkanen, R., Huttunen, S. \& Väisänen, S. 1981: The wax structure of the developing needles of Pinus sylvestris progenies infected by Lophodermella sulcigena. - Silva Fenn. 15: 377-381.

Jalkanen, R. \& Kurkela, T. 1984: Männynversoruosteen aiheuttamat vauriot ja varhaiset pituuskasvutappiot. Summary: Damage and early height growth losses caused by Melampsora pinitorqua on Scots pine. Folia For. 587: 1-15.

Jørstad, I. 1925: Norske skogsykdommer 1. Nåleträsykdommer bevirket av rustsopper, ascomyceter og fungi imperfecti. - Meddr. norske Skogfors Ves. 2(6): $19-186$

- 1928: Nord-Norges skogsykdommer. - Tidsskr. Skogbruk 36(8): $365-456$.

Kangas, E. 1931: Siikakankaan mäntytaimistojen tuhoista. Referat: Über die Schädigungen der Kiefernpflanzenbestände in Siikakangas. - Silva Fenn. 17: 1107.

- 1937: Tutkimuksia mäntytaimistotuhoista ja niiden merkityksestä. Referat: Untersuchungen über die in Kiefernpflanzenbeständen auftretenden Schäden und ihre Bedeutung. - Commun. Inst. For. Fenn. 24(1): 1304.

Karlman, M. 1980: Skador på Pinus contorta i norra Sverige 1979. - Sveriges SkogvFörb. Tidskr. 78(2): 14-26.

- 1984: Pathogens and other threats to Pinus contorta in northern Sweden. - Doctoral Thesis, Dept. Ecol. Bot. Univ. Umeå, $212 \mathrm{pp}$.

Krutov, V. 1979: O parazitnoj mikoflore iskusstvennyh fitocenozov sosny na vyrubkah Karel'skoj ASSR Murmanskoj oblasti. Summary: On the parasitic mycoflora of artificial pine phytocoenoses in the felling areas in the Karelian A.S.S.R. and Murmansk region. -Mikol. Fitopatol. 13: 342-349.

Kujala, V. 1950: Über die Kleinpilze der Koniferen in Finnland. - Commun. Inst. For. Fenn. 38(4): 1-121.

Kurkela, T. 1978: The life cycle of Lophodermella conjuncta a needle cast fungus on pine. - 3rd International Congress of Plant Pathology, Munich, 16-23 August, 1978, Abstracts of Papers, p. 129.

- 1979: Lophodermium seditiosum Minter et.al. sienen esiintyminen männynkaristeen yhteydessä. Summary: Association of Lophodermium seditiosum Minter et.al. with a needle cast epidemic on Scots pine. - Folia For. 393: $1-11$

Kurkela, T. \& Jalkanen, R. 1981: Deformations and susceptibility of pine needles to Lophodermella sulcigena resulting from imblanced nutrient status. - In: Millar, C. (ed.) Current research on conifer needle diseases. Proc. IUFRO W.P. on Needle Diseases, Sarajevo 1980: $37-41$.
Lagerberg, T. 1910: Om gråbarrsjukan hos tallen, dess orsak och verkningar. - Medd. Stat. Skogsförs. anst. 7: 127174.

Liro, J.I. 1924a: Männyn neulasten harmaatauti. - Tapio 17: $118-121$.

- 1924b: Tärkeimmät tuhosienet. Ed. 2. - 405 pp. Helsinki.

Martinsson, O. 1982: Svampsjukdomar på contortatall. Summary: Pathogenic fungi on lodgepole pine. Sveriges Skogvförb. Tidskr. 1-2: 57-58.

Millar, C. 1970: Role of Lophodermella species in premature death of pine needles. - Rep. Forest Res., Lond. 1970: $176-178$.

Mitchell, C., Williamson, B. \& Millar, C. 1976a: Hendersonia acicola on pine needles infected by Lophodermella sulcigena. - Eur. J. For. Path. 6: 92-102.

Mitchell, C., Millar, C. \& Haworth, M. 1976b: Effect of the needle-cast fungus Lophodermella sulcigena on growth of Corsican pine. - Forestry 49: 153-158.

Münch, E. \& Tubeuf, K. 1910: Eine neue Nadelkrankheit der Kiefer, Pinus silvestris. - Naturwiss. Zeitschrift für Forst- und Landwirtsch. 8(1): 39-44.

Rainio, Y.E. 1906: Sienien aikaansaamasta havupuiden karistetaudista (Schyttekrankheit). - Suomen Metsänhoitoyh. Julk. 23(2): 85-151.

Roll-Hansen, F. 1969: Soppsykdommer på skogtraer. - 144 pp. Vollebeck.

Rostrup, E. 1883: Fortsatte undersøgelser over snyltesvampes angreb paa skovtraeerne. - Tidsskr. Skovbrug 6: 199-300.

Selby, J. 1980: Field afforestation in Finland and its regional variations. - Commun. Inst. For. Fenn. 99(1): 1-126.

Staley, J. \& Bynum, H. 1972: A new Lophodermella on Pinus ponderosa and P. attenuata. - Mycologia 64: $722-726$

Terrier, C. 1944: Über zwei in der Schweiz bisher wenig bekannte Schüttepilze der Kiefern: Hypodermèlla sulcigena (Rostr.) v.Tub. und Hypodermella conjuncta Darker. - Phytopath. Z. 14: 442-449.

Vaartaja, O. 1951: Alikasvosasemasta vapautettujen männyn taimistojen toipumisesta ja merkityksestä metsänhoidossa. Summary: On the recovery of released pine advance growth and its silvicultural importance. Acta For. Fenn. 58(3): 1-133.

Varmola, M. 1980: Männyn istutustaimistojen ulkoinen laatu. Summary: The external quality of pine plantations. - Folia For, 451: 1-21.

Watson, A. \& Millar, C. 1971: Hypodermataceous needleinhabiting fungi on pines in Scotland. - Trans. Bot. Soc. Edinb. 41: 250 .

Williamson, B., Mitchell, C. \& Millar, C. 1976: Histochemistry of Corsican pine needles infected by Lophodermella sulcigena (Rostr.) v. Höhn. - Ann. Bot. 40: $281-288$. 